\title{
ピアノ演奏動作にみる人間らしい手指の動き
}

\section{Natural Smooth Motion of a Hand and Finger in Piano Playing}

\author{
○学 山本 和樹 (奈良先端大) 上田 悦子 (奈良産業大) 末永 剛 (奈良先端大)
} 正 栗田 雄一 (奈良先端大) 松本 吉央 (奈良先端大) 正 小笠原 司 (奈良先端大)

\author{
Kazuki YAMAMOTO* ${ }^{*}$ Etsuko UEDA**, Tsuyoshi SUENAGA*, Yuichi KURITA*, \\ Yoshio MATSUMOTO*, Tsukasa OGASAWARA*, \\ *Nara Institue of Science and Technology (NAIST) \\ **Nara Sangyo University \\ kazuki-ya@is.naist.jp
}

In this paper, we propose that what are the natural smooth motion in piano playing. Piano playing motion data are measured by using motion capture system. We examined what natural smooth motion is by questionnaire for twelve subjects and analyzed $Z$ axis finger velocity. The analytical result showed that waving motion relates to smoothness.

Key Words: Motion Analysis, Motion Capture, Piano Playing

\section{1.はじめに}

人間の自然な動作を解析し生成する試みは、ロボット, CGなど様々な分野で研究が取り組まれている $[1]$. 中でも 手指は第二の顔ともいわれるほど表情が豊かであり，再現 が難しい部位である。このような手指動作のうち、ピアノ 演奏動作に着目した。関口ら [2] がピアノ演奏の自動生成 手法の提案を行っているが, 人間らしいリアルな動作生成 には至っていない。ピアノ演奏動作は打鍵というインパク 卜を伴った指先の動作拘束を含んでおり,この打鍵動作を 基に解析を進める事が可能である。本研究の最終目標は, 楽譜情報を入力し，自然な演奏動作を表現する手指動作の $\mathrm{CG}$ アニメーション生成手法を提案し, 最終的にロボット ハンドに人間が弾いている様なピアノ演奏を行わせる事で ある。

本稿では，最終目標への第一ステップとして，「人間らし い(生き生きとしている)」と多くの人が感じるようなピア ノ演奏動作を解析することで，どのような動作特徵に対し て人が「人間らしい」と感じるのかを考察した結果を示す.

\section{2. リアルなピアノ演奏動作生成}

人間らしいピアノ演奏動作生成は以下のようなフローで 行うことを想定している.

1. 楽譜情報から指先位置情報を求力, 逆運動学によって 打鍵時の手指と腕の姿勢を求める.

2. 得られた打鍵時姿勢を, 楽譜情報による強弱などを用 いてつなぐ事で基本の演奏動作を生成する.

3. 基本演奏動作に対して，人間らしい動作特徵を付加 し，リアルな演奏動作へと変形する.

このなかでは，3に焦点を絞り，「人間らしい動作特徵」 が演奏動作にどのように現れるかを調べるため, 人間の演 奏動作を測定し解析する. Loehr [3] らは演奏時楽譜認識 による運指方法の違いによる動作特徽を解析している。こ れらの従来研究では，打鍵に直接関係する指のみの解析し かしていないが，本研究では，手首と肘の動作が「人間ら しい演奏動作」にあたえる影響は大きいと考え，指に加え

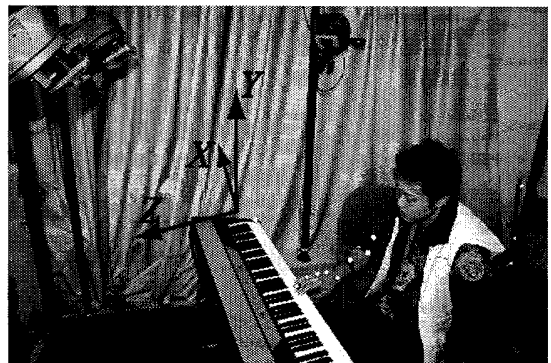

Fig. 1 Overview of experiment

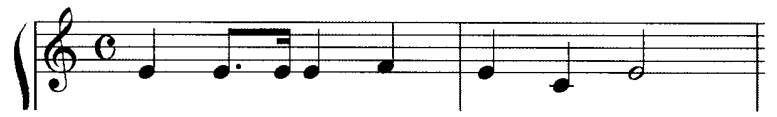

Fig. 2 Score (Chopin: Etude Op25 No.11)

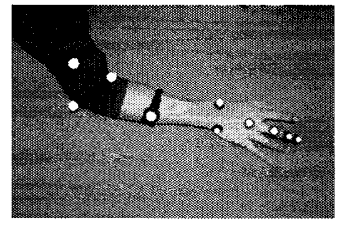

(a)

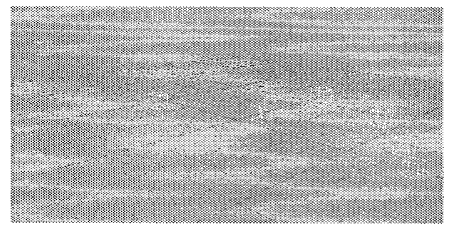

(b)
Fig. 3 Markers of motion capture system

て腕部まで含めた演奏動作を取り扱い，解析を行なう。

3. 動作計測と解析

3.1 解析対象データの取得

図 1 に示すように MIDI データが保存可能な電子ピア， を用いて，演奏動作を光学式モーションキャプチャによっ て取得する。今回は右手の中指だけを動作計測対象とし, 図 3(a) に示すように指先，DIP 関節，PIP 関節，MP 関 節, 手首, 前腕, 时, 上腕部の合計 10 点にマー力を付け三 次元位置を計測する。

実験は，8名の被験者が右手の中指一本を用いて，図 2 に示す Chopin の Etude Op25 No.11(木枯し) の冒頭 2 小節を演奏するというタスクを行った。また，全体的に強 く弾く場合（フォルテ）と弱く弾く場合（ピアノ）の２回 をそれぞれ被験者に行わせ，16 個の演奏動作を取得した。 


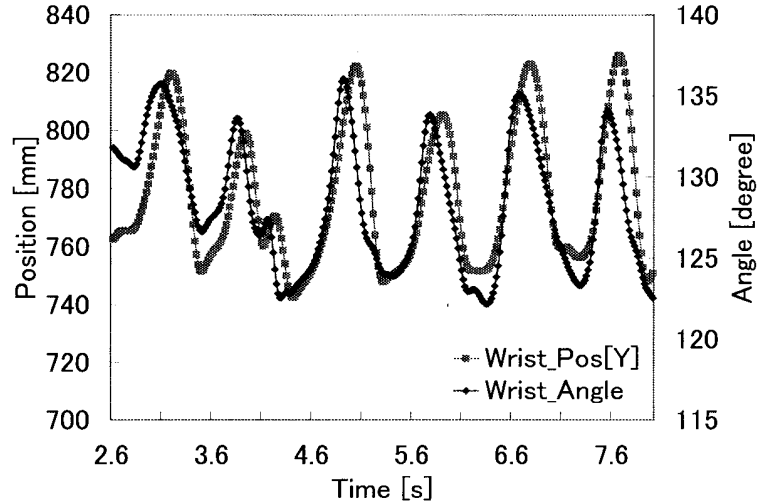

Fig. 4 Wrist joint position and angle (the most lively motion)

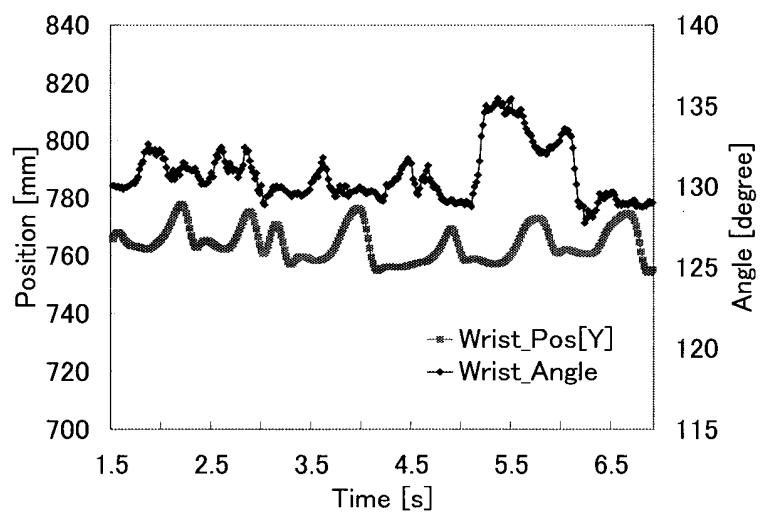

Fig. 5 Wrist joint position and angle (the least lively motion)

取得した動作デー夕を，図 3(b) のようなマーカーの位 置情報のみを提示するCGによって別の被験者 12 名に示 し，人間が弾いている事が明確に感じられるかを主観評価 させた。具体的には「生き生きとした」の度合いを 5 段階 評価させた。得られた評価と 16 種類の演奏動作を関連付 け, 解析を行った。

\section{2 解析結果}

評価の結果，最も評価が高かった演奏動作例（評価の平 均值 3.9) に注目する。動作を見ていくと，関節位置の変動 に伴って関節角度が遅延して変化する動作が，「生き生きと した」指標において評価が高い。これはいわゆる関節物体 における「しなりのある動作」だと言うことができる、評 価値の最高と最低の被験者それぞれの動作について, 手首 関節の $Y$ 軸方向（上下方向）の位置と関節角度の関係を図 4 と図 5 に示す. 評価が高い動作（図 4) では関節位置と角 度に相関があり，かつピーク位置が関節角度より少し遅れ て位置が振れている。一方, 評価が低い動作（図 5) では このような相関が見られない。このように，関節位置と関 節角度が関連付いて動作することが生き生きと見える要因 の一つだと考えられる。

打鍵に直接関係する動作は， $X$ 軸方向（ピア）鍵盤方 向）と $Y$ 軸方向の手指動作であるが, 今回の解析では, 演 奏に不要な動きとも言える $Z$ 軸方向（奥行き方向）の動き にも着目した。図 6 は，横軸に「生き生きとした」指標の 平均值, 縦軸に, MP 関節位置 $Z$ 軸方向の速度の二乗平均 平方根 (RMS) 值をとり, プロットしたグラフである.グ

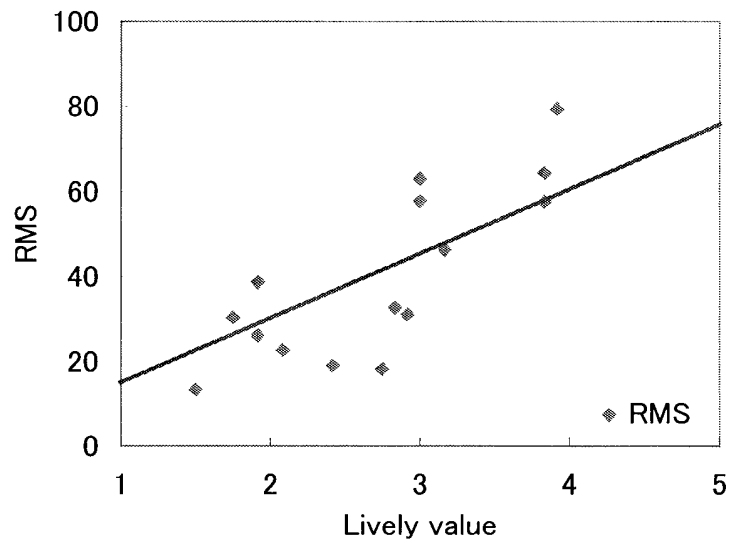

Fig. 6 Lively average and RMS reference

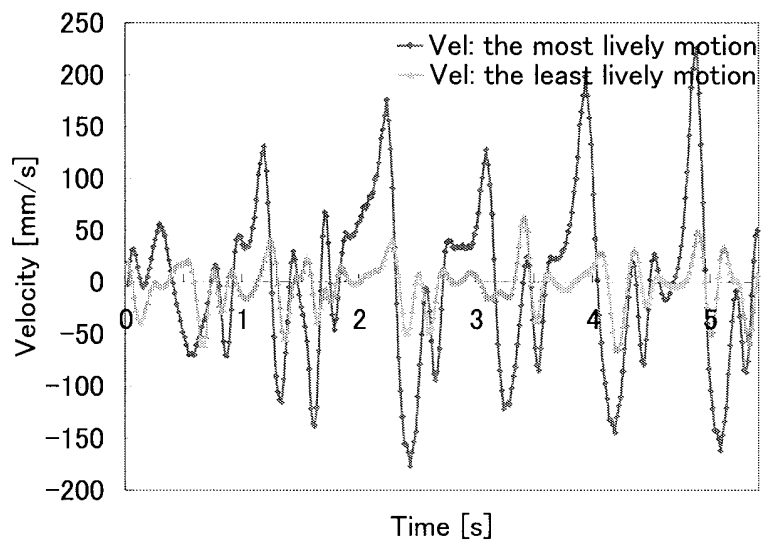

Fig. 7 Finger velocity (the most and least lively motion)

ラフには正方向の相関が読み取られ，Z軸方向の動きが生 き生きとした動きの要素であることが分かった。また，図 7 は評価が高い動作と低い動作の $Z$ 軸方向における指の速 度のグラフである。これより奥行き方向である $Z$ 軸方向の 不要な動きに対しても，指が頻繁に動いていることが示さ れた。

\section{4. まとめと今後の課題}

本稿では，モーションキャプチャを用いてピアノ演奏動 作を取得し，さらに人間らしさという観点から動作の特徵 解析を行った。 その結果, しなりの動作や $Z$ 軸方向の動き 万が，人間らしさの要素と考えられる生き生きとした演奏 動作であることが分かった. 今後は演奏動作の解析として 指一本加十本に拡張し，指同士の協調性についても注目 し解析するとともに，演奏動作の生成手法についても取り 組んでいく予定である.

\section{文献}

[1] Lucas, K., Michael, G. and Frederic, P., "Motion Graphs," in Proceedings of the 29th annual conference on Computer graphics and interactive techniques SIGGRAPH 2002, vol.21, pp473-482.

[2] 関口博之, 英保 茂, ”計算機によるピアノ演奏動作 の生成と表示”, 情報処理学会論文誌, Vol.40, No.6, pp2827-2837, 1999.

[3] Loehr, J. D. and Palmer, C., "Cognitive and biomechanical influences in pianists' tapping", Experimental Brain Research, Vol.178, 518-528, 2007. 